\title{
Front Matter: Volume 9429
}

, "Front Matter: Volume 9429," Proc. SPIE 9429, Bioinspiration, Biomimetics, and Bioreplication 2015, 942901 (4 May 2015); doi: 10.1117/12.2195670 Health Monitoring, 2015, San Diego, California, United States 


\title{
PROCEEDINGS OF SPIE
}

\section{Bioinspiration, Biomimetics, and Bioreplication 2015}

\author{
Akhlesh Lakhtakia \\ Mato Knez \\ Raúl J. Martín-Palma \\ Editors
}

9-11 March 2015

San Diego, California, United States

Sponsored by

SPIE

Cosponsored by

American Society of Mechanical Engineers (United States)

Optical Society of Southern California (United States)

Cooperating Organizations

Intelligent Materials Forum (Japan)

Jet Propulsion Laboratory (United States)

National Science Foundation (United States)

Published by

SPIE 
The papers included in this volume were part of the technical conference cited on the cover and title page. Papers were selected and subject to review by the editors and conference program committee. Some conference presentations may not be available for publication. The papers published in these proceedings reflect the work and thoughts of the authors and are published herein as submitted. The publisher is not responsible for the validity of the information or for any outcomes resulting from reliance thereon.

Please use the following format to cite material from this book:

Author(s), "Title of Paper," in Bioinspiration, Biomimetics, and Bioreplication 2015, edited by Akhlesh Lakhtakia, Mato Knez, Raúl J. Martín-Palma, Proceedings of SPIE Vol. 9429 (SPIE, Bellingham, WA, 2015) Article CID Number.

ISSN: 0277-786X

ISBN: 9781628415322

Published by

SPIE

P.O. Box 10, Bellingham, Washington 98227-0010 USA

Telephone +1 3606763290 (Pacific Time) · Fax +1 3606471445

SPIE.org

Copyright (C) 2015, Society of Photo-Optical Instrumentation Engineers.

Copying of material in this book for internal or personal use, or for the internal or personal use of specific clients, beyond the fair use provisions granted by the U.S. Copyright Law is authorized by SPIE subject to payment of copying fees. The Transactional Reporting Service base fee for this volume is $\$ 18.00$ per article (or portion thereof), which should be paid directly to the Copyright Clearance Center (CCC), 222 Rosewood Drive, Danvers, MA 01923. Payment may also be made electronically through CCC Online at copyright.com. Other copying for republication, resale, advertising or promotion, or any form of systematic or multiple reproduction of any material in this book is prohibited except with permission in writing from the publisher. The CCC fee code is 0277-786X/15/\$18.00.

Printed in the United States of America.

Publication of record for individual papers is online in the SPIE Digital Library.

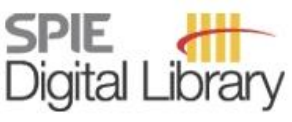

SPIEDigitalLibrary.org

Paper Numbering: Proceedings of SPIE follow an e-First publication model, with papers published first online and then in print. Papers are published as they are submitted and meet publication criteria. A unique citation identifier (CID) number is assigned to each article at the time of the first publication. Utilization of CIDs allows articles to be fully citable as soon as they are published online, and connects the same identifier to all online, print, and electronic versions of the publication. SPIE uses a six-digit CID article numbering system in which:

- The first four digits correspond to the SPIE volume number.

- The last two digits indicate publication order within the volume using a Base 36 numbering

system employing both numerals and letters. These two-number sets start with 00, 01, 02, 03, 04, $05,06,07,08,09,0 A, 0 B \ldots 0 Z$, followed by 10-1Z, 20-2Z, etc.

The CID Number appears on each page of the manuscript. The complete citation is used on the first page, and an abbreviated version on subsequent pages. 


\title{
Contents
}

\author{
vii Authors \\ ix Conference Committee
}

\section{BIOMATERIALS I}

942907 Paradigm for design of biomimetic adaptive structures (Keynote Paper) [9429-1]

OPTICS AND PHOTONICS I

942909 Exploring polarization features in light reflection from beetles with structural colors (Invited Paper) [9429-3]

9429 OA In $\times A_{1}-x N$ chiral nanorods mimicking the polarization features of scarab beetles [9429-4]

9429 OB The artificial beetle, or a brief manifesto for engineered biomimicry [9429-5]

9429 OC Light emission from compound eye with conformal fluorescent coating [9429-6]

9429 OD Electromagnetic response of the protective pellicle of Euglenoids: influence of the surface profile [9429-7]

\section{ADHESION}

9429 OF Switchable bio-inspired adhesives (Invited Paper) [9429-9]

\section{VISUAL AND ACOUSTIC SENSING}

9429 OK A predictive model for artificial mechanical cochlea [9429-14]

FLIGHT

$9429 \mathrm{OL} \quad$ A low cost simulation platform for flapping wing MAVs [9429-15]

9429 OM A three dimensional unsteady iterative panel method with vortex particle wakes and boundary layer model for bio-inspired multi-flap wings [9429-16]

942900 Dynamic response of a piezoelectric flapping wing [9429-58] 
9429 OP Fin propulsion on a human-powered submarine [9429-19]

$94290 Q \quad$ Biologically inspired robots elicit a robust fear response in zebrafish [9429-20]

9429 OR Artificial heart for humanoid robot using coiled SMA actuators [9429-21]

9429 OS Modeling of the energy savings of variable recruitment McKibben muscle bundles [9429-22]

9429 OT Design and fabrication of a three-finger prosthetic hand using SMA muscle wires [9429-23]

ROBOTICS II

9429 OU An insect-inspired flapping wing micro air vehicle with double wing clap-fling effects and capability of sustained hovering [9429-24]

9429 OV Soap film flow visualization investigations of oscillating wing energy harvesters [9429-25]

\section{OPTICS AND PHOTONICS II}

9429 0X Characterization of natural photonic structures by means of optimization strategies [9429-27]

\section{OPTICS AND PHOTONICS III}

$94290 Z$ Biomimetics, color, and the arts (Invited Paper) [9429-29]

942912 Simple mass-production method of substrate-free powders for applications of the Morpho-colored materials [9429-32]

\section{SYSTEMS AND DEVICES}

942913 Development of a frequency-modulated ultrasonic sensor inspired by bat echolocation (Invited Paper) [9429-33]

942915 A synthetic leaf: the biomimetic potential of graphene oxide [9429-35]

942916 Efficiency testing of hydraulic artificial muscles with variable recruitment using a linear dynamometer [9429-36]

942917 Variable deflection response of sensitive CNT-on-fiber artificial hair sensors from CNT synthesis in high aspect ratio microcavities [9429-37] 
942919 Behavior of an adaptive bio-inspired spider web [9429-39]

POSTER SESSION

9429 ID Motion generation of peristaltic mobile robot with particle swarm optimization algorithm [9429-44]

9429 IE Effects of contact cap dimension on dry adhesion of bioinspired mushroom-shaped surfaces [9429-45]

9429 IF Electrowetting of liquid polymer on petal-mimetic microbowl-array surfaces for formation of microlens array with varying focus on a single substrate (Best Student Paper Award) [9429-46]

$94291 \mathrm{~K} \quad$ The effect of the abdomen deformation on the longitudinal stability of flying insects (Best Student Paper Award) [9429-55]

$94291 \mathrm{~L} \quad$ Exploration of electric properties of cement compared to bone: streaming potential and piezoelectirc properties [9429-56]

$94291 \mathrm{M}$ Improving energy efficiency in robot limbs through hydraulic dangle (Best Student Paper Award) [9429-57] 
Proc. of SPIE Vol. $9429942901-6$

Downloaded From: https://www.spiedigitallibrary.org/conference-proceedings-of-spie on 26 Apr 2023 Terms of Use: https://www.spiedigitallibrary.org/terms-of-use 


\section{Authors}

Numbers in the index correspond to the last two digits of the six-digit citation identifier (CID) article numbering system used in Proceedings of SPIE. The first four digits reflect the volume number. Base 36 numbering is employed for the last two digits and indicates the order of articles within the volume. Numbers start with 00, 01, 02, 03, 04, 05, 06, 07, 08, 09, 0A, 0B...0Z, followed by 10-1Z, 20-2Z, etc.

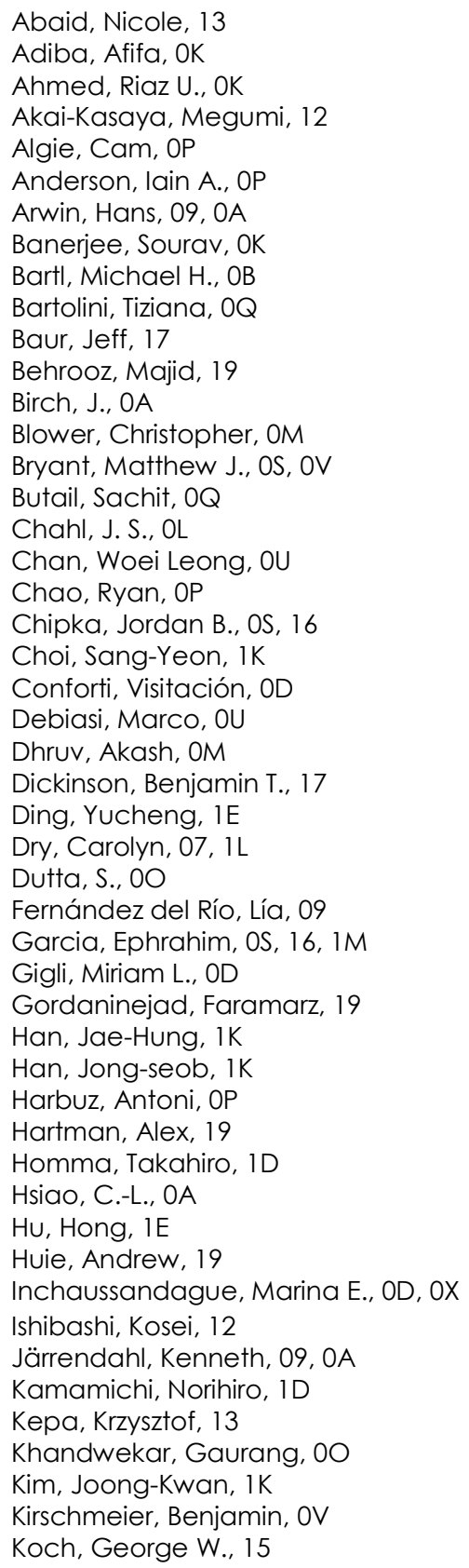

Kok, J.M., OL Kondash, Corey, 17 Kroner, Elmar, OF Kumar, Alok, 00 Kuwahara, Yuji, 12 Ladu, Fabrizio, $0 Q$ Lakhtakia, Akhlesh, OB, OC Lamb, Marilla, 15 Landin, Jan, 09

$\mathrm{Li}$, Xiangmeng, IF

$\mathrm{Li}$, Xiangming, $1 \mathrm{E}, 1 \mathrm{~F}$

LU, Benjamin, OP

Luna, Ana, OX

Macías, Demetrio, $\mathrm{OX}$ Macrì, Simone, $0 Q$ Magnusson, Roger, 09, 0A Mahapatra, D. Roy, 00 Martín-Palma, Raúl J., OC Maschmann, Matthew R., 17 Meller, Michael A., OS, 16, $1 \mathrm{M}$ Mendoza-Galván, Arturo, 09 Miller, Amy E., OC Morgan, Eric R., 15 Nguyen, Quoc-Viet, OU

Panitz, Sarah G., OQ

Phillips, David, 17

Pocock, Benjamin, OP

Porfiri, Maurizio, $0 Q$

Potnuru, Akshay, OR

Pulsifer, Drew P., OC Reich, Gregory, 17

Saito, Akira, 12

Sandström, P., OA

Schenk, Franziska, OZ Seelecke, Stefan, OT Severin, Benjamin, 17 Shafer, Michael W., 15 Shao, Jinyou, $1 \mathrm{E}, 1 \mathrm{~F}$ Simone, Filomena, OT Skigin, Diana C., OD, OX Slinker, Keith, 17

Tadesse, Yonas, OR Tian, Hongmiao, 1E, IF Tolivia, Analía, OD Venkatesh, S., 00 Vial, Alexandre, OX Vochezer, Daniel, OP Wang, Yue, $1 \mathrm{E}$ Whitman, Julian S., IM 
Wickenheiser, Adam M., OM

York, Alexander, 0T

Zheng, Lingyue, 19

Proc. of SPIE Vol. $9429942901-8$

Downloaded From: https://www.spiedigitallibrary.org/conference-proceedings-of-spie on 26 Apr 2023 Terms of Use: https://www.spiedigitallibrary.org/terms-of-use 


\section{Conference Committee}

Symposium Chairs

Victor Giurgiutiu, University of South Carolina (United States)

Christopher S. Lynch, University of California, Los Angeles

(United States)

\section{Symposium Co-chairs}

Jayanth N. Kudva, NextGen Aeronautics, Inc. (United States)

Theodoros E. Matikas, University of loannina (Greece)

Conference Chair

Akhlesh Lakhtakia, The Pennsylvania State University (United States)

Conference Co-chairs

Mato Knez, CIC nanoGUNE Consolider (Spain)

Raúl J. Martín-Palma, Universidad Autónoma de Madrid (Spain)

Conference Program Committee

Yoseph Bar-Cohen, Jet Propulsion Laboratory (United States)

Steven F. Barrett, University of Wyoming (United States)

Michael H. Bartl, The University of Utah (United States)

Javaan S. Chahl, Defence Science and Technology Organisation (Australia)

Francesco Chiadini, Università degli Studi di Salerno (Italy)

Susan A. Frost, NASA Ames Research Center (United States)

Marina Inchaussandague, Universidad de Buenos Aires (Argentina)

Sunghoon Kwon, Seoul National University (Korea, Republic of)

Gabriel A. Miller, San Diego Zoo (United States)

Bert Müller, Basel University Hospital (Switzerland)

Maurizio Porfiri, Polytechnic Institute of New York University (United States)

Akira Saito, Osaka University (Japan)

Jayant Sirohi, The University of Texas at Austin (United States)

Diana C. Skigin, Universidad de Buenos Aires (Argentina)

Session Chairs

1 Biomaterials I

Akhlesh Lakhtakia, The Pennsylvania State University (United States) 
2 Optics and Photonics I

Kellar Autumn, Lewis \& Clark (United States)

3 Adhesion

Carolyn Dry, Natural Process Design, Inc. (United States)

4 Biomaterials II

Akira Saito, Osaka University (Japan)

5 Visual and Acoustic Sensing

Javaan S. Chahl, University of South Australia (Australia)

6 Flight

Maurizio Porfiri, New York University (United States)

7 Robotics I

Nicole Abaid, Virginia Polytechnic Institute and State University (United States)

8 Robotics II

Shad J. Roundy, University of Utah (United States)

9 Optics and Photonics II

Mato Knez, CIC nanoGUNE Consolider (Spain)

10 Optics and Photonics III

Hans Arwin, Linköping University (Sweden)

11 Systems and Devices

Iain A. Anderson, The University of Auckland (New Zealand)

12 Biomaterials III

Masatsugu Shimomura, Chitose Institute of Science and Technology (Japan) 